\title{
Research on the development and technology selection of green building in China
}

\author{
WANG Yi-hong ${ }^{1, a}$ LIAN Xiao-nan ${ }^{1, b^{*}}$ \\ ${ }^{1}$ School of Management, Tianjin University of Technology, Tianjin 300384, China
}

\begin{abstract}
This paper collects the previous data of green building in China and divides the different development stages of green building in China. The paper collects the existing data of green building in China, and expounds the development status of green building in China from different perspectives. In addition, the selection of green building technology in China is investigated, summarized and analyzed to find out the problems in the practical application of different technologies and put forward solutions, so as to obtain the suitable reference for the selection of green building technology in China.
\end{abstract}

\section{Introduction}

In recent years, the investment in the construction industry has been growing rapidly with the unit of one trillion yuan every year. Construction sites are everywhere in the city, all of which are closely related to China's urbanization. In 2017, the State Council issued the National Population Development Plan (2016-2030), which set the goal of "70\% of China's permanent urban population by 2030". The National Bureau of Statistics released the Statistical Communique of 2019 National Economic and Social Development on February 28, 2020, in which it was pointed out that China's urbanization exceeded $60 \%$ for the first time in 2019 , and the urban population increased from 480 million to 850 million. The progress of urbanization is encouraging, but the problems it brings are also worth noting, such as "ghost cities" and "empty cities" caused by extensive expansion, and serious environmental pollution. Under the above background, the performance evaluation of urban rail transit projects with construction period evaluation and operation period evaluation as the main body is mostly based on the position of the government or social capital. As one of the important stakeholders, the public's willingness to participate and interest appeals are not. Often overlooked.

To solve these problems, we should vigorously promote green buildings. Green building has the advantages of saving resource and protect the environment, reduce pollution, can according to the natural ecological environment, by using the basic principle of ecology, architecture and other subjects and advanced science and technology, to seek the balance between nature, society, architecture and human, harmony and unification, to create a comfortable, healthy working and living environment, and also can control architecture for the dependence and consumption of natural resources, realizing the virtuous circle between energy in environment and architecture, is conforms to our country building energy consumption increasing cases of a kind of energy saving, environmental protection, comfortable building types. Therefore, in order to promote the reform of China's construction industry and avoid the generation of energy crisis, the development of green building is imminent.

This paper collects the previous data of green building in China and divides the different development stages of green building in China. The paper collects the existing data of green building in China, and expounds the development status of green building in China from different perspectives. In addition, the selection of green building technology in China is investigated, summarized and analyzed to find out the problems in the practical application of different technologies and put forward solutions, so as to obtain the suitable reference for the selection of green building technology in China.

\section{Literature review}

The origin of green Architecture can be traced back to the 1960s, when Italian-American architect Pablo Solemness first combined Ecology and Architecture and proposed a new concept of Arcology in his book Architecture: A City in the Ideal of Man.

Compared with the development of green building abroad, the development of green building in China is lagging behind but fast. Some scholars divide the

Corresponding author: blianxiaonan515@163.com 
development of green building in China into four stages, and regard the release of Green Building Evaluation Standard in the third stage as a key node in the construction of China's green building technical standard system. The development of green building in China has made rapid progress since the release of the standard. Similarly, some scholars from the perspective of the national policy, think our country since 2006, released after the green building evaluation standard, by 2013, respectively, introduced the "civil building green design specification", "green building evaluation technology regulations (try out)", "green building evaluation technology conditions added (run using partial) 7, such as the green building codes and standards. Separately issued by the national related departments on the printing of the green building assessment identity management approach (trial) > notification ", "about the printing < green building assessment identification rules amended (try out) > documents such as notice," about to speed up the implementation opinion "to promote the development of green architecture in our country, such as working file, you can see our country to promote green building development dynamics of the big.

It is concluded that compared with traditional building technology, green building technology is not only a kind of technological progress, but also a kind of ideological progress. Green building technology can be defined as a "sustainable" concept, with the characteristics of land saving, energy saving, water saving, material saving and optimization of indoor and outdoor environment technology. Although the green building techniques in China starts late, but, under the government actively promote technology development is very fast, in numerous provisions under the support of policy, the selection of green building techniques have certain standards, many scholars also the improvement of green building technology and choose to make the corresponding research, but applied to practical projects, or the lack of system support, technology selection of chaos, appear the phenomenon such as disorderly use, no, no.

\section{Development history of green building in China}

\subsection{The budding stage}

In the 1980s and before, China's green building development was in the embryonic stage. In the early 1980s, China began to reform and open up, and the economy recovered. At the same time, China's housing shortage, which has been overstocked for many years, began to emerge, leading to a nationwide construction boom. Due to the low level of construction in China at that time, the construction quality of the construction was poor, and the basic consideration of thermal insulation was not taken into account. The problem of cold in winter and hot in summer was prominent, and the energy consumption was huge, and the problem of energy waste was serious. In this case, various places began to improve the building performance of the way to study, the most representative is the northern area of the raw earth building. Raw earth building has the advantages of convenient materials, low cost and simple construction. Meanwhile, it can significantly improve the living environment of the building. It can be said that it is the prototype of green building in China and the model of building technology adapted to local conditions in China.

\subsection{Basic research stage}

From the 1990s to the beginning of the 20th century, it is the stage of basic research on green building in China. 1994 "China's agenda 21", "national major science and technology industrial engineering - 2000 well off the urban and rural residential industry project of science and technology" and in 1996 the law of the People's Republic of China human settlements development report published and start can be seen as important landmark in this stage, this is a symbol of our country to increase and improve the quality of living environment to make a deep step higher requirements and safeguard measures. Many problems in the construction industry, such as, occupation of land, resource consumption and energy consumption of buildings such as indoor and outdoor environment has gradually become the focus of attention, to the road of sustainable development of construction industry become the consensus of government and industry, a number of green architecture with the exploratory research began, involves the theory mainly includes the ecology, such as political science, economics and management, and thus in terms of green building appeared such as the overall ecological view, externality theory, the interests of bo abandon theory, rent-seeking theory, a comprehensive evaluation theory, etc. At the same time, China introduced foreign green building theory. After that, China introduced foreign green building technology and research results through research projects funded by the government and international cooperation. The research of domestic scholars and the nourishment of foreign products have laid a foundation for the development of green building in China.

\subsection{Developmental stage}

In the 21 st century, China's green building has entered the development stage. Different from the previous two stages, China began to practice green building in this stage. Among them, the ultra-low energy consumption laboratory building of Tsinghua University was built in 2005 and started construction in 2002. The ecological office building of Shanghai Academy of Building Sciences was built in September 2004 and started construction in November 2003. In 2005, it passed LEED Silver Certification and became China's first green building commercial project. It was put into use in 2005 and became China's first LEED Gold Award certification project for the Ministry of Science and Technology's Agenda 21 Research Center office building. These four energy-efficient and green-themed buildings 
can be seen as a sign that China's green building is gradually becoming mature. In addition, China has successively released China Ecological Housing Technology Assessment Manual (2001), Green Olympic Building Evaluation System (2004) and Housing Performance Assessment Technical Standard (2005). On the basis of the above three green building technology systems, in 2006, GB/ T50378-2006 "Green Building Evaluation Standard" was issued in the form of national standards. Subsequently, the Ministry of Housing and Urban-Rural Development issued relevant supporting policies, marking the establishment of an official green building technology standard system in China. By 2010, China's green building had developed rapidly, from a slow development in the early 21 st century to a rapid development, and green building began to become the development direction of China's construction industry.

\section{Research on Green Building Technolo gy Selection in China}

\subsection{Statistical analysis of green building technol ogy selection}

At the present stage, there are two main types of green buildings in China: green residential buildings and green public buildings. Due to their different uses, the design, construction and operation considerations of the two buildings are also different. In order to control the construction quality of green buildings and standardize the construction standards, the state has carried out star evaluation of green buildings and set up a green building evaluation index system. The index system of green building evaluation includes control item, general item and optimal item. The control item is a necessary condition for green building, which involves the mandatory provisions in the relevant standards. If not met, one vote will be rejected. The general term and the preference are the optional conditions for grading green buildings, among which the preference is the option with greater difficulty in realization, strong comprehensibility and high greenness, and it is also the key technology of green building.

\subsubsection{Residential building}

Residential buildings are buildings that meet the needs of private life. Residential building is the main type of building, and it is also a building type with high requirements for building energy conservation. It is very important to choose appropriate green building technology to reduce the energy consumption of residential building. China is in the stage of rapid urbanization development, and the real estate industry is the biggest beneficiary of urbanization development and also undertakes the work of urban renewal. Energysaving renovation of new residential areas and existing residential buildings is the key issue that must be paid attention to at present. Residential buildings are generally in the form of homes with families as units, which are required to meet People's Daily living needs and ensure the safety, convenience and privacy of living, which makes the overall form of residential buildings similar. Domestic residential buildings are dominated by high-rise slab-type residential buildings, which makes it possible to consider the green building technology selection uniformly and learn from each other. Because the indoor space of residential buildings is relatively independent, the situation of each household is different, so the energy consumption is not easy to control. Therefore, the selection of energy saving technology for habitable buildings should start from the direction of energy control, and the energy saving work should be detailed to the residents. China has carried out star evaluation on residential buildings, which are divided into one-star residential buildings, two-star residential buildings and three-star residential buildings, in an effort to evaluate residential buildings from the design source and make them conform to the standards of green buildings.

Green buildings in China are mainly divided into residential buildings and public buildings, and one star, two star and three stars rating are set respectively. This section will first introduce the classification of green buildings, and then analyzed the selection of green building technology on the selected samples of 300 green building projects in China.

One-star residential building is the residential building with the lowest star rating, so the rating requirements are not high and there is no requirement for the preferred items. As long as the control items are satisfied, the general items meet the requirements for the number of one-star items.

A two-star residential building is a mid-star residential building with certain rating requirements: at least three preferences are required, and all the controls must be satisfied.

Three-star residential buildings are the highest rated residential buildings, so the rating requirements are high: at least five preferences are required, and all the controls must be satisfied.

\subsubsection{Public buildings}

In this paper, the subway, right, the rail transit and the post bar and so on six parts of the subway of urban rail transit related post bar, 80 posts, a total of 2153 comments to filter and the summary, found in the posted messages, comments more reflects the personal life circumstances around, public awareness of the urban rail projects without operators, under the guide of the public urban rail project construction period and operation period of focus more on average, to build up phase involves a number of statements.

Public buildings are non-productive buildings for people to carry out social activities. With the rapid expansion of public activities and interpersonal communication in modern society, public buildings have become the most widely used architectural types. Public buildings are different from residential buildings in terms of architectural form and internal structure because 
of their use functions. Public buildings have many kinds, large volume, diverse functions and large energy consumption, so the technology selection can not be generalized. Similar to residential buildings, China also carries out star rating for public buildings, which are divided into one-star public buildings, two-star public buildings and three-star public buildings.

One-star public buildings are the public buildings with the lowest star rating, so the rating requirements are not high and there is no requirement for the preferred items. As long as the control items are satisfied, the general items meet the requirements for the number of one-star items.

A two-star public building is a medium-star public building with certain rating requirements: at least six preferences are required, and all controls must be satisfied.

A three-star public buildings are the highest rated residential buildings, so the rating requirements are high: at least 10 preferences are required, and all controls must be satisfied.

\subsubsection{Statistics on the application of green building technology}

Among the 300 selected projects, their regions contain all 5 climate zones, including 25 cold regions, 64 cold regions, 156 hot in summer and cold in winter, 48 hot in summer and warm in winter, and 7 mild regions. Project type and star distribution are shown in Table 1, 2 .

Table 1. Technical requirements for indoor environmental quality

\begin{tabular}{|c|c|c|c|}
\hline & $\begin{array}{l}\text { residential } \\
\text { building }\end{array}$ & $\begin{array}{l}\text { public } \\
\text { buildings }\end{array}$ & total \\
\hline One-star & 61 & 68 & 129 \\
\hline two-star & 43 & 77 & 120 \\
\hline three-star & 23 & 28 & 51 \\
\hline total & 127 & 173 & 300 \\
\hline
\end{tabular}

Table 2. Statistical table of energy saving technologies

\begin{tabular}{|c|c|c|c|c|}
\hline \multirow[t]{2}{*}{ Technical term } & \multicolumn{4}{|c|}{ Choose the proportion } \\
\hline & $\begin{array}{l}\text { total } \\
\text { propor } \\
\text { tion }\end{array}$ & $\begin{array}{l}\text { One- } \\
\text { star }\end{array}$ & $\begin{array}{l}\text { Two- } \\
\text { star }\end{array}$ & $\begin{array}{l}\text { Three- } \\
\text { star }\end{array}$ \\
\hline $\begin{array}{c}\text { Distributed } \\
\text { cogeneration of } \\
\text { heat, power and } \\
\text { cooling }\end{array}$ & 0 & 0 & 0 & 0 \\
\hline $\begin{array}{c}\text { Waste heat } \\
\text { recovery }\end{array}$ & 0 & 0 & 0 & 0 \\
\hline $\begin{array}{c}\text { renewable } \\
\text { energy sources }\end{array}$ & 22 & 0 & 20 & 82 \\
\hline illumination & 100 & 100 & 100 & 100 \\
\hline $\begin{array}{l}\text { building energy- } \\
\text { subentry measure }\end{array}$ & 100 & 100 & 100 & 100 \\
\hline $\begin{array}{l}\text { Air conditioning } \\
\text { working }\end{array}$ & 100 & 100 & 100 & 100 \\
\hline $\begin{array}{l}\text { Manipulating } \\
\text { Envelope and } \\
\text { Fenestration }\end{array}$ & 100 & 100 & 100 & 100 \\
\hline Evaluation of & 64 & 63 & 68 & 60 \\
\hline
\end{tabular}

\begin{tabular}{|c|c|c|c|c|}
\hline $\begin{array}{c}\text { daily water } \\
\text { consumption }\end{array}$ & 87 & 100 & 100 & 82 \\
\hline $\begin{array}{c}\text { water saving } \\
\text { system }\end{array}$ & 40 & 4 & 65 & 100 \\
\hline $\begin{array}{c}\text { Unconventional } \\
\text { water use }\end{array}$ & 80 & 100 & 60 & 100 \\
\hline $\begin{array}{c}\text { high performance } \\
\text { material }\end{array}$ & & \\
\hline
\end{tabular}

\section{Conclusion}

With the increasing shortage of resources and the deterioration of the environment, green building has gradually become popular, and the greening in the construction process has become the object of people's attention. The concept of green buildings was introduced in the 1990s, and by the end of 2019, green buildings accounted for more than 50 percent of new civil buildings in China's cities and towns. At the same time, China has a large population base and a large area of existing buildings. In the development of green buildings, no matter it is the construction of new buildings or the transformation of existing buildings, it has great development potential.

\section{Acknowledgment}

Fund program : National Social Science Foundation of China (20BGL220)

\section{References}

1. John Danish, John Cray, Kemohan, and Anne S a Imond. Post-occupancy in new Zealand, Design Studies 3 (April 1982): $77 \sim 83$.

2. EPSTEN, DAGMAR B.l. German innovation for High-performance Buildings (part1)[J].Environment al Design and Construction, 2014, 17(4): 18-20.

3. Hoffmann, Dunjald.hoffmann@umwelt-campus.d e; Weih, Martin2.Limitations and improvement of the potential utilisation of woody biomass for energ $\mathrm{y}$ derived from short rotation woody crops in Swede $\mathrm{n}$ and Germany $[\mathrm{J}]$.Biomass and Bioenergy, 2005, 284(3): 267-279.

4. Georges, L; Berne, M; Mathisen, HM. Air he ating of passive houses in cold climates: Investigatio $\mathrm{n}$ using detailed dynamic simulations[ $\mathrm{J}]$. Building an d Environment, 2014, 74: 1-12.

5. Nashrulla, Tasneem. British companies offer lowcarbon solutions for city[J]. HindustanTimes, 2010. 